\title{
Hubungan Eksekutif dan Legislatif pada Era Presiden Joko Widodo Periode 2014-2019
}

\author{
Antonius Jeremias Beso; Restu Rahmawati \\ Universitas 17 Agustus 1945 Jakarta \\ Email: restu.rahmawati3@gmail.com
}

\begin{abstract}
ABSTRAK
Tulisan ini mengkaji tentang penerapan sistem presidensial dalam demokrasi modern di dalam hubungan eksekutif dan legislatif pada era Presiden Joko Widodo 2014-2019. Peneliti menggunakan metode penelitian kualitatif dengan pendekatan studi kasus. Peneliti mengumpulkan data primer dalam bentuk wawancara mendalam, dan observasi. Adapun untuk data sekunder peneliti peroleh dari foto dan studi literatur. Dalam penelitian ini, menghasilkan studi bahwa implementasi hubungan eksekutif dan legislative di era kepemimpinan Jokowi 2014-2019 dapat dilihat dari semakin menguatnya eksekutif yang ditandai oleh dominannya partai pendukung pemerintah. Dengan kuatnya dukungan partai politik maka akan semakin mudah pemerintah dalam hal ini eksekutif menguasai parlemen. Lalu dampak hubungan eksekutif dan legislatif pada era kepemimpinan Joko Widodo periode 2014-2019 bagi sistem presidensial di era demokrasi modern, dapat kita ambil kesimpulan bahwa dampak menguatnya sistem presidensial yakni ketika eksekutif mendapat dukungan dari partai-partai mayoritas di parlemen dan kekuatan oposisi yang tidak seimbang, maka akan membentuk pola-pola oligarki, yang hanya menguntungkan sebagian elit politik di Indonesia. Lambat laun karena sudah tidak adanya budaya check and balance antara ekskutif dan legislatif, maka dampaknya adalah melemahnya Demokrasi di Indonesia.
\end{abstract}

Kata kunci: Sistem Presidensial, Demokrasi, Oligarkhi, Partai Politik

\section{PENDAHULUAN}

Tulisan ini akan mengkaji tentang penerapan sistem presidensial pada era kepemimpinan Joko Widodo pada periode 2014-2019, yakni terkait implementasi hubungan eksekutif dan legislatif. Alasan peneliti melakukan penelitian terkait hubungan antara eksekutif dan legislatif pada masa pemerintahan presiden Jokowi di periode 20142019 ini, adalah karena secara empirical problem pasca pemilu 2014 yang lalu terjadi perpecahan yang seimbang diantara dua kekuatan pendukung Jokowi-Yusuf Kalla dan pendukung Prabowo - Hatta.

Begitu juga di parlemen, partai pendukung keduanya terbagi menjadi dua kekuatan yang besar, sehingga banyak maneuver-manuver politik yang tercipta di sana. 
Seperti contoh maneuver partai PPP yang awalnya beroposisi dengan pemerintah, seketika mendukung calon presiden pemenang pemilu 2014, yakni Jokowi-JK. Lalu diikuti oleh partai PAN dan partai Golkar sehingga konfigurasi kekuatan di parlemen menjadi berubah. Fenomena tersebut sangat menarik untuk diteliti lebih dalam, guna mengetahui bagaimana hubungan eksekutif dan legislatif di dalam parlemen periode 2014-2019, dalam menggodok suatu kebijakan, apakah dengan terbelahnya parlemen menjadi dua kekuatan menghasilkan begitu banyak kepentingan sehingga dalam menentukan satu kebijakan cenderung alot dan memakan waktu, atau justru melahirkan sebuah fenomena demokrasi yang kompleks dalam politik Indonesia selama jenjang waktu 2014-2019.

Jika dibandingkan dengan era presiden Susilo Bambang Yudhoyono, partai-partai yang beroposisi dan mendukung pemerintah, memiliki kekuatan yang sangat berbeda. Lihat saja koalisi yang terbentuk di era presiden SBY di 2004, hampir seluruh partai politik menjadi bagian dari pendukung pemerintah, kecuali PDIP yang saat itu satusatunya partai politik yang memilih beroposisi. Selanjutnya di periode 2009, partai oposisi diisi oleh partai PDIP, Gerindra, dan Hanura, sementara semua partai politik lainnya memilih untuk mendukung pemerintah. Berikut bagan sebaran kekuatan partai di parlemen periode 2014-2019.

Tabel 1.1 Perbandingan Kekuatan Partai-Partai di Parlemen priode 2004 - 2009 dan 2009 - 2014.

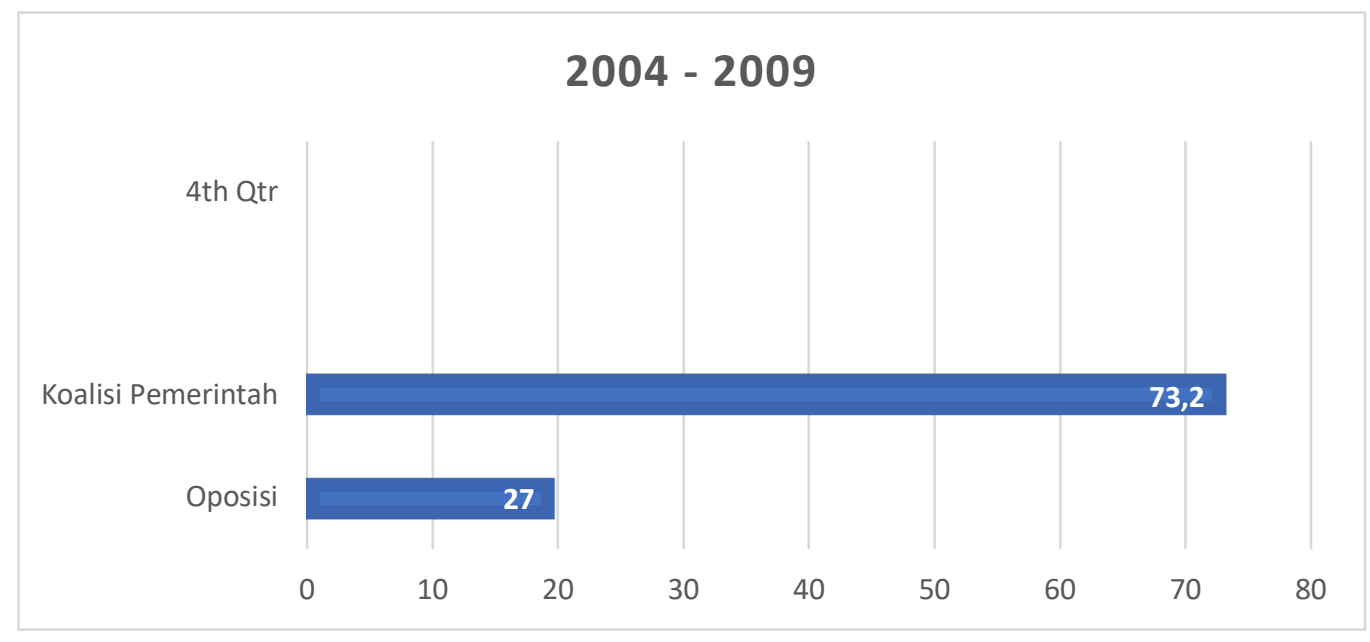




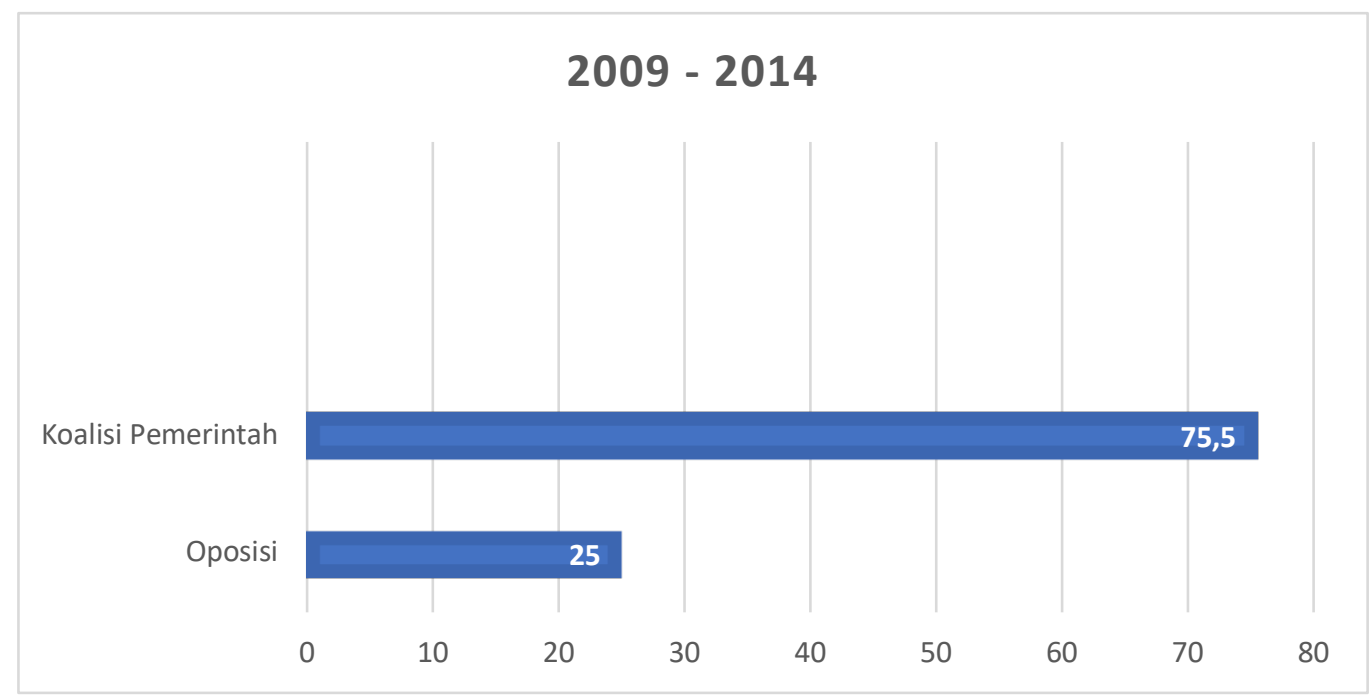

(Sumber: https://tirto.id/selalu-ada-jatah-menteri-bagi-yang-tak-betah-jadioposisi-dDWg, diakses pada 13 Februari 2020, pukul 13.39).

Dapat dilihat perolehan kursi partai-partai politik di parlemen pada periode 2004 - 2009 dan 2009 - 2014, pada 2004 perolehan suara partai oposisi hanya mampu mengantongi $27 \%$ suara, sedangkan koalisi pendukung pemerintah mampu mengantongi hingga 73,2 suara di parlemen. Hal ini berbeda dengan 2009 partai oposisi mengalami penurunan perolehan suara, hanya sebanyak $25 \%$, itupun dari jumlah partai yang bergabung sudah ditambah dari Gerindra dan Hanura, Koalisi pemerintah mengalami penambahan suara hingga $75,5 \%$ di parlemen.

Kondisi ini berimbas pada dikuasainya parlemen oleh partai-partai pendukung pemerintah, sehingga segala kebijakan pemerintah yang membutuhkan persetujuan DPR, akan dengan mudah di tanda-tangani tanpa argumentasi dan perlawanan yang berarti. Namun di era presiden SBY, tak jarang partai-partai yang bekoalisi dengan pemerintah, justru sering berselisih paham dengan pemerintah terkait dengan kebijakan yang sedang digodok. Seperti contoh ketika kenaikan harga BBM, partai-partai pendukung pemerintah terbelah menjadi dua, ada yang setuju dan ada yang tidak setuju, hal ini merupakan hal yang sering terjadi di era presiden Susilo Bambang Yudhoyono dan merupakan hal biasa. Dapat dikatakan, pada era presiden SBY, walaupun parlemen dikuasai oleh pendukung pemerintah, namun eksekutif tidak selalu mendapatkan dukungan suara dari partai-partai pendukungnya di DPR dalam penggodokan kebijakan-kebijakan tertentu. Pada saat itu eksekutif bukan hanya mendapatkan perlawanan dari partai oposisi, tapi juga sering 
mendapatkan perlawanan dari partai-partai pendukung pemerintah sendiri. Hal ini menunjukan bahwa sistem presidensial berjalan sehat dan masih seimbang dengan terus adanya check and balance antara eksekutif dan legislatif di era presiden SBY. Efek dari sistem presidensial yang seimbang ini adalah terbentuknya pemerintahan demokrasi yang efektif, yang tidak bertitik tumpu pada satu lembaga pemerintahan, pressure terhadap kebijakan eksekutif bukan hanya datang dari oposisi, tapi juga dari partai-partrai pemerintah itu sendiri.

Lebih jauh, jika kita membicarakan sistem presidensial, maka kita membicarakan tentang adanya pemisahan cabang-cabang seperti eksekutif dan legislatif. Dengan kekuasaan eksekutif berada diluar lembaga legislatif. Ini sangat berbeda dengan sistem parlementer yang dicirikan oleh lembaga legislatif sebagai ajang utama penyusunan undang-undang dan kekuatan eksekutif. Definisi paling sederhana mengenai perbedaan dua sistem ini adalah eksekutif lebih independent dari pada legislatif. Eksekutif pada tingkat presidensial lebih independent dibanding dengan legislatif, sedangkan pada tingkat parlementer, terdapat saling ketergantungan dan saling berkaitan dalam kapasistas-kapasitas eksekutif dan legislatif. (Legowo, 2014: 20)

Independensi eksekutif dalam sistem presidensial, dimanifestasikan dalam pemilihan umum secara langsung yang terpisah antara kepala eksekutif dengan anggotaanggota legislatif, anggota-anggota eksekutif juga tidak boleh merangkap sebagai anggota legislatif. Kepala pemerintahan pada sistem parlementer, dipilih dari anggota legislatif yang memperoleh suara dukungan mayoritas. Demikian juga anggota-anggota kabinet, direkrut dari anggota-anggota legislative (Legowo, 2014: 21) Presiden dalam sistem presidensial memiliki posisi yang relatif kuat, dan tidak mudah untuk dijatuhkan, karena rendah subyektif, seperti rendahnya dukungan politik. Namun, masih ada mekanisme untuk mengontrol presiden. Untuk itu agar tidak terjadi otoriterisme maka dibentuklah sistem check and balance antara lembaga tinggi negara, hal inilah yang disebut dengan cheking power with power (Syafiie, 2002: 53).

Selanjutnya penerapan sistem presidensial dalam demokrasi modern ini, penting untuk diteliti dan telisik lebih dalam, guna mengindetifikasi bagaimana kepemimpinan sistem presidensial di era Presiden Joko Widodo 2014 - 2019, agar kita memahami bagaimana hubungan antara eksekutif dan legislatif di Indonesia selama masa kepemimpinan nya ini, dan bagaimana dampak sistem presidensial dalam demokrasi 
modern di Indonesia. Hal ini semata-mata, agar tetap terjadi check and balance yang seimbang, antara lembaga eksekutif dan legislatif sebagai pemerhatinya.

Pemilu tahun 2014 dimenangkan oleh pasangan Joko Widodo dan Jusuf Kalla, untuk memimpin Indonesia pada periode 2014-2019. Pada detik-detik akhir pembentukan kabinet Indonesia kerja, banyak partai-partai oposisi pemerintah yang turut bergabung dalam jajaran koalisi pemerintah. Bila kita mencermati koalisi yang telah terbentuk ini, cenderung bersifat office seeking (hanya terfokus pada perebutan kursi politik) dan bukan berdasarkan kesamaan program kerja atau platform masing-masing partai yang ada. Hal itu terlihat jelas, bahwa partai-partai yang tergabung dalam koalisi adalah untuk mencari posisi jabatan dalam pemerintahan dan bisa juga terkait oleh keuntungan financial. Dengan kata lain, koalisi yang dipraktikan oleh partai-partai politik kita ini cenderung bersifat instant karena lebih berdasarkan oleh kepentingan politik jangka pendek.

Dengan adanya fenomena ini, maka kekuatan politik di parlemen akan berubah, dikarenakan banyaknya partai yang bergabung dengan koalisi pemerintah, dibanding partai yang memilih beroposisi. Berikut data kekuatan partai-partai di parlemen tahun 2014 - 2019 (lihat table 1.2)

Tabel 1.2 Perbandingan Kekuatan Partai-Partai di Parlemen 2014 - 2019

\begin{tabular}{|c|c|c|}
\hline $\begin{array}{c}\text { Partai } \\
\text { Pendukumg } \\
\text { Pemerintah }\end{array}$ & $\begin{array}{c}\text { Partai Oposisi } \\
\text { Pemerintah }\end{array}$ & $\begin{array}{c}\text { Partai } \\
\text { Netral }\end{array}$ \\
\hline PDIP & Gerindra & Demokrat \\
$19,4 \%$ & $13,04 \%$ & $10,89 \%$ \\
\hline Nasdem & PKS & \\
$6,25 \%$ & $7,14 \%$ & \\
\hline Hanura & & \\
\hline $2,86 \%$ & & \\
\hline PKB & & \\
$8,39 \%$ & & \\
\hline PAN & & \\
\hline $8,75 \%$ & & \\
\hline Golkar & & \\
$16,25 \%$ & & \\
\hline
\end{tabular}




\begin{tabular}{|c|c|c|}
\hline PPP & & \\
$6,96 \%$ & & \\
\hline Total & Total & Total \\
$\mathbf{6 8 , 8 6} \%$ & $\mathbf{2 0 , 1 8}$ & $\mathbf{1 0 , 8 9}$ \\
\hline
\end{tabular}

(Sumber : https://www.medcom.id/nasional/politik/nN98v6GK-ini-daftarperolehan-kursi-dpr-ri-tiap-parpol, diakses pada tanggal 07 February 2020, Jam 0:53 Wib).

Jika kita melihat table di atas, menggambarkan perbandingan kekuatan koalisi di parlemen yang begitu jauh, pada mulanya partai oposisi menguasai perolehan kursi diatas 60\% lebih, namun paska tahun 2015 beberapa partai pendukung oposisi memutuskan bergabung dengan partai pendukung pemerintah, sehingga terbentuklah perolehan kekuatan kursi yang sangat jauh di parlemen. Dapat kita lihat, bahwa partai pendukung pemerintah menguasai hingga $68,86 \%$, sedangkan partai oposisi hanya tersisa $20,18 \%$, padahal jika kita melihat kekuatan partai oposisi paska pemilu 2014 memperoleh hingga $60 \%$ lebih kursi di parlemen, perolehan kursi ini akhirnya hanya menyisakan 10,89\% perolehan yang dimiliki partai netral, yakni partai Demokrat.

Fenomena ini menggambarkan langsung dampak dari dikuasainya parlemen oleh partai-partai pendukung pemerintah, dan hanya sedikit partai yang akan berperan sebagai oposisi seperti misalnya PKS dan Gerindra. Berdasarkan hal tersebut maka akan memungkinkan kepemimpinan periode pertama presiden Joko Widodo akan diuntungkan, baik secara kebijakan, maupun keputusan yang dikeluarkan DPR, lalu check and balance yang ada juga tidak akan kuat karena dari partai yang beroposisi sendiri tidak akan memiliki suara banyak diparlemen. Dampak dari banyaknya partai-partai yang bergabung dengan koalisi pemerintah ini dikhawatirkan akan menimbulkan otoriterisme kekuasaan, dimana sistem presidensilnya tidak akan tersentuh oleh parlemen, justru parlemen akan mendukung segala kebijakan presiden, hal ini juga akan mengamankan posisi presiden baik di legislatif maupun di eksekutif itu sendiri, karna pasti akan menghilangnya sistem yang mengawasi segala kinerja eksekutif. Namun perlu kita ketahui juga, pada berjalannya sistem presidensial di Indonesia tak jarang posisi presiden sering dilemahkan oleh parlemen. Lewat sistem multi partainya parlemen memiliki suara yang kuat, karna terdapat banyak kepentingan disitu. 
Secara teoritical problem terdapat penelitian terdahulu yang menyebutkan bahwa Presiden seringkali mengalami resistansi karena peran legislatif lebih dominan dalam sistem multi partai. Sebenarnya posisi presiden RI sangat kuat karena presiden dipilih langsung oleh rakyat bukan dipilih oleh DPR. Tetapi dalam hal penerbitan dan pengesahan perundang-undangan presiden perlu dukungan DPR. DPR yang merupakan lembaga negara, justru menjadi resistansi dalam sistem pemerintahan kita, karena mereka bias dengan kepentingan primordial masing-masing, dan cenderung mengutamakan kepentingan partainya. Seperti contoh pada masa kepemimpinan presiden Abdurahman wahid, terjadi konflik yang tajam antara presiden dengan DPR, MPR, TNI, dan kepala Polri. Konflik dengan DPR tampak ketika Abdurahman wahid menolak panggilan pansus Bulog yang melaksanakan hak angket atas kasus bulog. Konflik dengan MPR diawali ketika MPR menganggap Abdurahman wahid melakukan pelanggaran dalam menetapkan pejabat kapolri dengan mempercepat SI MPR. Gus Dur menolak hadir dalam sidang istimewa MPR karena sidang istimewa dianggap melanggar tata tertib. Dua hari kemudian presiden mengeluarkan dekrit maklumat presiden antara lain pembekuan MPR. MPR menolak dekrit dengan mencabut ketetapan MPR No.VII/MPR/1999 tentang pengangkatan Abdurahman Wahid sebagai presiden. Dengan ketetapan MPR tersebut maka Abdurahman Wahid diberhentikan dari jabatannya sebagai presiden (Pradi, 2007: $14)$.

Hal ini berbanding terbalik dengan penelitian dari Juan Linz (Linz, 1990 : 1994) yang menyebutkan bahwa presiden dan DPR sama-sama kuat, karna sama-sama memiliki legitimasi langsung dari rakyat. fenomena ini biasa disebut sebagai "the perils of presidentialsm". Disini terdapat 3 masalah bawaan, yang pertama, adanya dual legitimasi, karna sama-sama dipilih oleh rakyat maka baik legislatif maupun eksekutif memiliki legitimasi yang sama kuat. Kedua, rigidity, baik legislatif maupun eksekutif memiliki masa jabatan yang tetap. Kecuali dengan alasan-alasan kejahatan konstitusi dan kriminal presiden tidak dapat diberhentikan di tengah jalan. Ketiga, majoritan tandency. Linz berpendapat bahwa pemerintahan eksekutif yang tidak mendapatkan dukungan mayoritas dari parlemen akan berakibat kepada lemahnya Demokrasi, atau dampak yang paling buruk adalah gagalnya pemerintahan.

Merujuk pada teoritical problem tersebut, maka penelitian ini akan mencoba melihat bagaimana implementasi penerapan sistem presidensial di Indonesia khususnya 
pada era kepemimpinan Jokowi periode 2014-2019. Apakah situasi yang digambarkan penelitian sebelumnya masih akan terjadi di Indonesia atau sebaliknya sistem presidensial akan semakin menguat karena eksekutif dalam hal ini presiden sangat bergantung dengan keterwakilan koalisinya di parlemen, guna mempengaruhi segala kebijakan dan mengamankan posisinya diparlemen, dengan sebisa mungkin menarik pengaruh seluruh partai politik di Indonesia. Karna jika tidak begitu dengan sistem multi partai yang ada, posisi presiden cenderung lemah dibandingkan dengan parlemen.

\section{METODE PENELITIAN}

Dalam penelitian ini, penulis menggunakan metode penelitian kualitatif, metode penelitian kualitatif merupakan suatu pendekatan dalam melakukan penelitian yang berorientasi pada gejala-gejala yang bersifat alamiah karena orientasinya dapat dilihat dari adanya perkembang politik dimasyarakat serta isu-isu yang masih hangat dan fresh, maka sifatnya naturalistik dan mendasar atau bersifat kealamiahan serta tidak bisa dilakukan di laboratorium melainkan harus terjun dilapangan. (M. Nazir: 1986, 13) Sehubungan dengan masalah penelitian ini, maka peneliti mempunyai rencana kerja atau pedoman pelaksanaan penelitian dengan menggunakan metode kualitatif, dampak yang dikumpulkan berupa pendapat, tanggapan, informasi, konsep-konsep dan keterangan yang berbentuk uraian dalam mengungkapkan masalah. (Hadari: 1994, 51) Agar lebih memahami dan mengetahui khasus terkait penerapan sistem presidensial dalam demokrasi modern studi: Hubungan antara ekesekutif dan legislatif pada era kepemimpinan Joko Widodo periode 2014-2019.

Penelitian dalam metode kualitatif ini menggunakan pendekatan studi kasus dimana studi kasus merupakan sebuah metode memberikan karangka atau prosedur penelitian yang harus diikuti. (Yin, 2002: 32) Studi kasus sebagai proses penelitian " $A$ case study is an empirical inquiry that investigates a contemporary phenomenon (the “case”) within its real-life context, especially when the boundaries between phenomenon and context may not clearly evident'. Sebuah studi kasus penelitian bertujuan untuk menguji pertanyaan dan masalah penelitian, yang tidak dapat dipisahkan antara fenomena dan konteks dimana fenomena tersebut terjadi. 


\section{PEMBAHASAN}

\section{Implementasi Hubungan Eksekutif dan Legislatif Pada Era Kepemimpinan Joko Widodo Periode 2014-2019}

Dalam sistem Presidensial, persoalan koalisi pemerintah dengan dukungan kekuatan minoritas dapat berdampak pada jatuhnya pemerintahan.(Muhtadi, Burhanudin, 2013: 63). Dalam sistem ini mungkin saja seorang presiden didukung oleh gabungan partai koalisi minoritas di parlemen. Bagi sebagian kalangan, potensi masalah yang utama dalam sistem presidensial adalah terjadinya deadlock berkepanjangan antara pihak eksekutif dan juga legislatif. Hal ini tentu saja karena kedua lembaga ini berdiri masingmasing dan sama-sama memiliki legitimasi langsung dari rakyat, yang memungkinkan dua-duanya merasa memiliki hak untuk memperjuangkan kepercayaan rakyat. Kekhawatiran atas kelemahan ini telah disampaikan, misalnya oleh Linz dengan mengambil contoh pemerintahan Presidensial di Amerika latin.(Linz, 1990: 51). Hampir seluruh nagara di Amerika latin mengadopsi sistem presidensial multipartai, dan di beberapa negara sistem ini terbukti gagal, walaupun di beberapa negara lainya sistem ini tetap berjalan sampai dengan hari ini.

Searah dengan pendapat Linz, beberapa ahli kemudian menilai bahwa kombinasi antara sistem presidensial dengan sistem multipartai adalah kombinasi yang tidak menguntungkan (Nina, 2014: 114). Hal ini karena dampak yang dihasilkan dari kombinasi ini adalah pemerintahan tanpa kompromi yang dapat mengabaikan masukan dari parlemen atau sebuah pemerintahan demokrasi yang tidak efektif, dimana antara eksekutif dan legislatif bersikap saling meniadakan. Dalam situasi ini koalisi partai pendukung presiden di parlemen akan sangat menguntungkan, karena pada akhirnya akan berujung pada dua hal, yakni menopang sebuah pemerintahan yang oligarki, atau mengalami ketidakberdayaan untuk dapat menghindari tekanan legislatif. (Scott Mainwairing, 1993:26).

Melihat pada kondisi sebelum perhelatan pemilu 2014 digelar, ada beberapa partai politik yang mengalami peningkatan perolehan elektabilitas. Berdasarkan hasil survei yang dilaksanakan oleh Lembaga Survei Indonesia (LSI), elektabilitas PDIP melesat tajam, sementara berbanding terbalik dengan elektabilitas partai Demokrat yang sangat jauh, ibarat thermometer suhu badan Demokrat menjelang pemilu sangat jauh menurun. (Burhanudin Mutadi, 2013: 65). Bukan hanya PDIP yang melesat cepat tetapi Golkar pun 
mengalami hal yang sama, menurut survei pada awal Oktober 2012, PDI Perjuangan dan Golkar mendapat insentif elektoral dari kemerosotan partai Demokrat. Sekitar 21\% dari responden memilih PDI perjuangan, jumlah ini jauh meningkat dari pada perolehannya di 2009 sedangkan Golkar mendapat 19\% dukungan dari responden. (Burhanudin Mutadi, 2013: 66)

Pencaturan politik di awal 2014 kian memanas, dapat dilihat dari perdebatan ambang batas pencalonan presiden, dalam revisi UU No.42/2008 tentang pemilihan Presiden. Dua partai besar seperti PDIP dan Golkar, berjuang untuk tidak merevisi presidential threshold, sementara partai-partai lainnya, termasuk Demokrat, menyarankan beberapa revisi untuk itu. Jika ambang batas pada pilpres 2014 berhasil berubah, maka jumlah calon presiden yang bertanding pada 2014 pasti akan berubah , yakni lebih banyak lagi paslon yang bertanding. Namun sayangnya hal ini tidak terjadi, PDIP dan Golkar berhasil mempertahankan argumentasinya di parlemen.

Patut diakui kebijakan Megawati untuk menjadikan PDIP sebagai partai yang beroposisi selama 2004-2014 sebagai langkah awal pelembagaan oposisi secara konsisten pasca Reformasi 1998. Pada 2004 megawati menempatkan diri sebagai partai yang beroposisi dan tidak bersedia bergabung dengan kabinet SBY-JK, lalu PDIP juga aktif mengkritik kebijakan-kebijakan yang dikeluarkan oleh pemerintahan SBY. Hal konsisten ini menjadikan partainya sebagai salah satu partai yang mendapatkan popularitas cukup tinggi di pemilu 2014. Mereka terbukti sukses dengan strategi politiknya, selain itu pencalonan Jokowi sebagai calon presiden 2014 juga dapat dibilang sebuah langkah jitu yang diambil oleh PDIP, karena terbukti mampu mengangkat nama PDIP jauh lebih tinggi lagi, dengan memenangkan pemilu 2014.

Pada pemilu presiden 2014, Jokowi dan Jusuf kalla terpilih sebagai Presiden dan wakil presiden 2014-2019. Dengan terpilihnya Jokowi dan Jusuf kalla sebagai Presiden dan wakil Presiden 2014-2019, maka terjadilah polarisasi di DPR, yaitu antara pendukung Jokowi-JK yang membentuk Koalisi Indonesia Hebat (KIH) dan pendukung PrabowoHatta, yang membentuk Koalisi Merah Putih (KMP). Polarisasi tersebut akhirnya membentuk perseteruan politik yang panjang, setelah seluruh kursi pimpinan DPR diambil alih oleh Koalisi Merah Putih. Dalam perkembangannya perselisihan di DPR bukan hanya terjadi antara Koalisi Merah Putih dan Koalisi Indonesia Hebat, tetapi terjadi pula pelemahan kubu kekuatan oposisi karena beberapa partai pendukung KMP 
kemudian berbalik mendukung pemerintah. (Tuswoyo Admojo, 2016: 289). Polarisasi kekuatan politik di parlemen dimulai dengan adanya menuver politik yang dilakukan oleh PPP, lalu diikuti oleh PAN, dan yang terakhir Golkar. Padahal jika ketiga partai tersebut tidak berpindah haluan, posisi oposisi di parlemen sudah diatas kertas, karena telah mengantongi perolehan kursi di parlemen sebanyak 292 kursi DPR RI.

Dapat kita lihat dari table perbandingan diatas, koalisi Merah Putih yang diketuai Gerindra, sudah mengantongi perolehan kursi sampai 292, sementara koalisi Indonesia Hebat, yang diketuai oleh PDIP pada mulanya hanya mengantongi 208 kursi, dan partai Demokrat sebagai partai yang netral, mengantongi 61 perolehan kursi. Ini membuktikan, bahwa pada tahun 2014 paska pemilu, kekuatan partai oposisi begitu besar di parlemen. Namun pada tahun 2016, seketika perolehan kekuatan berbanding terbalikn beberapa partai oposisi seketika bergabung menjadi pendukung partai pemerintah, hal ini pertama kali diprakarsai oleh PAN, yang kemudian diikuti oleh Golkar dan Juga PPP.

Pada Implementasi hubungan eksekutif dan legislative di era kepemimpinan Jokowi 2014-2019 dapat dilihat dari semakin menguatnya eksekutif yang ditandai oleh dominannya partai pendukung pemerintah. Dengan kuatnya dukungan partai politik maka akan semakin mudah pemerintah dalam hal ini eksekutif menguasai parlemen. Seperti contohnya dengan mengubah UU tentang MPR, DPR, DPD, dan DPRD (UU MD3). Sebelum DPR periode 2014-2019 dilantik, partai-partai yang beroposisi berhasil memenangkan perselisihan terkait dengan mekanisme pemilihan pimpinan DPR. Oposisi mensetujui ketua DPR tidak otomatis dijabat oleh partai pemenang pemilu, melainkan dipilih dengan sistem paket. Lalu muncul protes dari partai-partai pendukung pemerintah, dengan alasan bahwa mereka memiliki 44\% suara di DPR dan oposisi 56\%. Dengan demikian mereka berhak atas 22 kursi pimpinan komisi dan alat kelengkapan DPR yang lain (Kompas.com, 1 November 2014).

Paska perhelatan pemilu 2014, partai-partai yang tergabung di dalam oposisi pemerintah atau KMP, mencoba memunculkan citra koalisi yang berorientasi kerakyatan di muka publik. Padahal jika dilihat dari kebijakan-kebijakan yang hendak direalisasikan, dapat di identifikasi mereka lebih dekat ke arah policy blind coalition (Koalisi yang tidak didasari atas pertimbangan kebijakan), meskipun mereka menempatkan Pancasila sebagai idiologi koalisinya. Sementara partai pendukung pemerintah atau Koalisi Indonesia Hebat yang dipimpin oleh PDIP, yang selama 2004-2009 menjustifikasikan diri sebagai partai 
yang berhaluan kerakyatan, ternyata beberapa partai di dalam Koalisi Indonesia Hebat juga tidak bisa dibilang berorientasi kerakyatan, contohnya seperti partai Nasdem, PKB dan PKPI, dimana aspek yang menyatukan mereka adalah karena sama-sama berhaluan Nasionalis yang didukung oleh konsep Trisakti dan Nawacita yang dijadikan dasar kebijakan pemerintah 2014-2019.

Dalam model koalisi-koalisi seperti ini, yang tidak didasari oleh kesamaan kebijakan, hubungan partai-partai pendukung akan bersifat lebih cair, tergantung pada kalkulasi kepentingannya masing-masing. Persoalan integritas dan solidaritas akan tergantung pada distribusi kepentingan terhadap anggota, serta pertimbanganpertimbangan pragmatis lainnya. (Tuswoyo Admojo, 2016: 303) Hal ini terbukti ketika beberapa partai yang tergabung di Koalisi Merah Putih mengalami konflik internal. Partai Golkar dan PPP sama-sama terbelah menjadi dua kubu, belakangan justru partai PAN lewat ketua umumnya yang baru yakni Zulkifli Hasan menyatakan sikap mendukung Pemerintah Joko Widodo - Jusuf Kalla. Pada perkembangannya, di dalam DPR sendiri mulai menunjukan polarisasi internal partai PPP dan Golkar. Hal itu misalnya terkait dengan persoalan dukungan dalam pencalonan Budi Gunawan sebagai kapolri dan persoalan RUU KPK. Menurut Said salahudin, Presiden melakukan kesalahan terkait konflik antara Polisi dan KPK (Republika.co.id, 8 Februari 2015). Meskipun kesalahankesalahan ini terjadi pada pihak presiden, tetapi melalui rapat konsultasi dengan seluruh pimpinan parlemen, semua masalah dapat diselesaikan dengan baik. Presiden kemudian mencalonkan kapolri baru, dan mengganti Budi Gunawan dengan alasan menimbulkan kegaduhan (Kompas.com, 6 April 2016).

Dalam isu usulan revisi UU KPK, beberapa elit PDIP didukung beberapa partai pendukung pemerintah/Koalisi Indonesia Hebat bersikeras untuk mengusulkan revisi tersebut, meskipun presiden kurang setuju. Padahal di lapangan penolakan-penolakan terus berdatangan dari masyarakat luas terhadap RUU KPK ini. Dalam perkembangannya dari 9 fraksi yang mengadakan rapat pada tanggal 10 Februari 2016 di Baleg (Badan Legislasi) DPR, untuk menetapkan Revisi Undang-undang KPK, satu-satunya partai yang menolak hanya partai Gerindra. Jika saat itu pemerintah juga menolak revisi tersebut, berarti nantinya partai oposisi justru bersikap sama dengan pemerintah dan publik.

Sikap politik partai Gerindra dapat di klasifikasikan menjadi beberapa poin. Yaitu pertama, partai ini mencoba aspiratif terhadap keinginan public. Kedua, partai ini tidak 
asal-asalan beda dengan pemerintah dalam mempersoalkan kebijakan, tidak peduli apakah sikap itu nantinya bertentangan dengan kebijakan pemerintah atau tidak. Ketiga, meskipun koalisi partai oposisi sangat lemah karena tidak didasari dengan kesamaan idiologi politik, dan secara hitung-hitungan sudah berkurang semenjak sepeninggalan beberapa partai koalisinya, namun mereka berhasil menujukan sikap yang tegas terhadap kepentingan rakyat. Hal ini dapat berdampak positif terhadap perilaku pemilih rakyat terhadap partainya.

Pada masa kepemimpinan Joko Widodo Periode 2014-2019 ini hubungan eksekutif dengan legislatif memperlihatkan kondisi yang tidak antagonistik. Rupanya pemerintahan presiden Jokowi di periode 2014-2019 mengembangkan komunikasi politik dengan menghilangkan relasi dominasi dalam hubungannya antara Presiden-DPR dan sebaliknya. Selama ini jabatan Presiden sangat di keramatkan, sehingga dalam hubungannya dengan parlemen terkesan adanya relasi dominan tersebut. Sementara relasi dominasi, pasti akan menghambat hubungan kelembagaan keduanya komunikasi mereka. Hal ini dikarenakan persyaratan dari sebuah konsensus yang penting dalam proses pelembagaan adalah ketika para pihak yang berkonsensus memiliki pemahaman tentang nilai-nilai dan norma yang disepakati bersama. Pemahaman tentang nilai dan norma akan menjadi pemahaman bersama ketika tidak ada relasi yang dominan. (Marsh dan Stoker, 2002: 118, Huntington, 2003: 16, Deliarnov 2006: 108).

Dengan tidak adanya relasi dominasi, berbagai strategi komunikasi politik dapat dilakukan, salah satunya dengan pertemuan-pertemuan informal antara eksekutif dan legislatif, hal ini bertujuan agar posisi eksekutif lebih menguat di parlemen. Diharapkan dari sini Presiden Jokowi dapat menyelesaikan political dead lock yang kemungkinan bisa saja terjadi. Hal ini selaras dengan pernyataan Djayadi Hanan, yang menjelaskan bahwa cara lain untuk mencegah kebuntuan pemerintahan adalah menjaga komunikasi yang intensif antara pemerintah dan parlemen. Pertemuan rutin yang formal dan informal, perlu selalu dijalankan oleh kedua belah pihak. (Kompas.com, 2014). Sebenarnya upaya Presiden Jokowi dalam menjaga implementasi hubungan denga legislatif adalah untuk tetap menjaga pengaruhnya di parlemen. Ditambah dengan pecahnya kekuatan oposisi, menambah mudahnya eksekutif menghegemoni legislatif.

Contohnya dalam kasus pencabutan subsidi BBM 2014 yang dilakukan pemerintahan Joko Widodo telah terjadi perbedaan sikap diantara Koalisi Merah Putih 
PKS secara gambling menolak kebijakan kenaikan harga BBM, sementara partai Golkar terjadi perbedaaan sikap antara ketua umumnya Aburidzal Bakrie, dengan Setya Novanto Ketua DPR RI. Saat itu Aburidzal Bakrie masih menunggu kebijakan dari pemerintah terkait, kompensasi bagi rakyat kecil dan bagaimana pemerintah mengatasi gejolak yang diakibatkan oleh kenaikan harga BBM (Kompas.com, 2014), saat itu ketua DPR RI Setya Novanto justru mendukung kebijakan tersebut. (CNNIndonesia.com, 2014).

Partai Gerindra sebagai pimpinan partai oposisi atau Koalisi Merah Putih, hanya menyatakan penyesalannya, dan memohon agar Presiden terketuk hatinya dan merubah keputusannya. Alasan dari partai Gerindra adalah naiknya inflasi yang dapat mencapai $3 \%$ dan kurang tepatnya waktu kebijakan dikeluarkan, karena saat itu harga minyak mentah sedang turun sekitar US \$73-74 per barel, atau 30\% lebih rendah dari asumsi APBN 2014. (Beritabuana.com, 2014). Artinya tidak adanya upaya-upaya perlawanan yang dilakukan oleh KMP terkait isu tersebut. Padahal pada saat itu banyak kekuatan dan elemen-elemen masyarakat yang menolak kebijakan tersebut.

Anehnya, partai-partai KMP yang sejak awal berambisi menguasai parlemen, ternyata juga sering tidak berdaya menghadapi pemerintahan dengan memanfaatkan kebijakan-kebijakan pemerintah yang bertentangan dengan visi misi partai-partai oposisi dan kepentingan rakyat. Namun pada saat partai-partai mulai menunjukan sikap kritisnya terhadap kebijakan pemerintah, yang ada justru beberapa partai koalisi seperti PAN, PPP, dan Golkar justru berpindah haluan mendukung pemerintah. Dan justru hanya menyisakan partai Gerindra dan PKS yang beroposisi, padahal keduanya berbeda secara idiologi dan arah pandang partai.

Meskipun pada akhirnya partai Gerindra dengan sikapnya yang konsisten menolak revisi UU KPK, yang akhirnya berimbas pada penundaan pengagendaan revisi UU KPK. Namun belakangan di akhir kekuasaan presiden Jokowi periode 2014-2019 hampir seluruh partai mendukung RUU KPK, sekalipun ada yang tidak mendukung mereka tidak menolak dan lebih bersifat pasif, demi menyelamatkan muka partai di hadapan publik. Hal ini menunjukan bahwa hegemoni eksekutif sudah mulai menguat seiring dengan berjalannya waktu, bahkan pengaruhnya bisa dirasakan sampai dengan ke partai-partai oposisi, hal ini terbukti bukan hanya terkait di dalam penggodokan kebijakan, akan tetapi terbukti dengan pecahnya kongsi Koalisi Merah Putih yang setengahnya justru ikut bergabung ke dalam koalisi partai pendukung pemerintah. 
Bahkan menurut Dave Laksono anggota DPR RI dari Fraksi Golkar mengatakan bahwa suara oposisi di parlemen bisa ditekan dengan lobby-lobby politik yang dilakukan oleh eksekutif maupun partai-partai pendukungnya di parlemen, ini menunjukan bahwa Koalisi Merah Putih yeng terbentuk menjadi oposisi tidak memiliki landasan beroposisi yang jelas, (wawancara langsung tanggal 25 Januari 2020, Pukul 12.00 WIB) padahal menurut Dahl, keberadaan koreksi dan partisipasi terhadap pemerintah jauh lebih utama ketimbang pemilu. Dalam sudut pandang ini demokrasi tidak semata dilihat sebagai persoalan pemilihan umum, tetapi sebuah budaya dan idiologi yang memuat seperangkat nilai yang harus disemaikan. (Firman Noor, 2016: 3). Pernyataan Dave Laksono diatas menunjukan bahwa ada ketidakmampuan partai oposisi untuk mempertahankan posisinya dalam mengkritisi pemerintah, koalisi ini sewaktu-waktu dapat hancur dengan lobbylobby politik yang ditawarkan oleh eksekutif. Lagipula sejak awal koalisi ini memang tidak memiliki kesamaan idiologi sebagai perekatnya, jadi mereka terbentuk memang hanya bertujuan memperoleh office seeking saja.

Indikasi-indikasi menguatnya Presidensial di periode 2014-2019 memang sudah keliahatan di pertengahan masa kepemimpinan Presiden Joko Widodo, hal ini terlihat ketika dengan mudahnya semua kebijakan-kebijakan pemerintah yang membutuhkan persetujuan DPR melanggeng dengan luwes, tanpa ada kritisi dan pengkajian terlebih dahulu. bahkan menurut Yosef T. Badewoda anggota DPR RI 2014-2019 dari Fraksi Demokrat mengatakan bahwa kelebihan dari banyaknya partai pendukung pemerintahan dan semua keinginan eksekutif selalu diaminin oleh legislative. Itu artinya bahwa semua program jalan, bukan hanya terkait prolegnas, tapi seluruh program pemerintah yang harus mendapatkan persetujuan dari DPR, itu seluruhnya dikabulkan dan selanjutnya berjalan. Jadi pemerintah tidak terganggu, itu untungnya. Akan tetapi kekurangannya adalah semua persoalan dan problem yang ada di seluruh kementrian dan BUMN semua, itu semua tidak terekspos/ tidak terbaca oleh masyarakat. Itu buruknya, jadi semua itu ABS aja, (Asal Bapa Senang). Sehingga pada akhirnya pemerintah sendiri yang jatuh korban. Selain itu, semua kementerian diisi oleh orang-orang partai, ketika mereka bermitra dengan DPR, itu semua diatur oleh partai, sehingga diskusi-diskusi dan pembahasan yang lebih dalam, itu tidak akan dapat. Setiap kritik-kritik dari oposisi, itu selalu dipatahkan semua, bisa lewat voting, maupun yang lainnya. (Hasil wawancara 
pribadi dengan Yosef T.Badewoda, anggota DPR RI Fraksi Demokrat tanggal 27 Januari 2020, Pukul 15.00 WIB).

Kekuatan partai pendukung pemerintah yang begitu kuat, membuat hubungan antara eksekutif dan legislatif tidak seimbang, maka terjadilah ketimpangan di parlemen antara KMP/Partai oposisi dengan KIH/Partai pendukung pemerintah. Hal ini berimbas jelas kepada tidak tereksposnya kasus-kasus panas di parlemen, seperti BPJS, Infrastruktur, dan lain sebagainya. Ini semua dikarnakan tidak adanya proses Check and Balance yang terjadi, kalaupun ada itu semua hanya di masa-masa awal kepemimpinan periode pertama, namun pada pertengahan hingga akhir masa kepemimpinan presiden di periode 2014-2019 terjadi hegemoni kekuasaan di parlemen sehingga menunjukan bahwa penerapan sistem Presidensial dalam demokrasi modern menguat.

Dari hasil wawancara diatas dapat dilihat bahwa masa kepemimpinan presiden Jokowi berbeda dengan jaman kepemimpinan Soesilo Bambang Yudhoyono, walaupun zaman kepemimpinan Soesilo Bambang Yudhoyono itu setgab bisa sampai 75\% memiliki kursi di DPR, namun ketika pengambilan keputusan, bukan hanya dissenting opinion yang ada, tetapi sikap yang berbeda, ketika dinaikan BBM partai pendukung pemerintah bisa berbeda sikap dengan pemerintah. Di zaman Presiden Jokowi, semuanya tidak ada. Menurutnya masa kepemimpinan ini, tidak memiliki equal position karena kebijakankebijakan yang diambil, di parlemen itu selalu selaras dengan eksekutif, seperti contoh ketika UU pemilu, kita ingin Presidensial threshold tidak 20\%, tapi diangka 10\%, tapi partai pendukung pemerintah solid, diangka 20\% dan itu menyebabkan dua kali Pilpres 2014 dan 2019 cuma diikuti oleh dua pasang calon, sehingga pada akhirnya kebijakan itu sangat menguntungkan Presiden Jokowi.

Selain pengaruh politik ekskutif terhadap legislatrif begitu kuat, terdapat juga beberapa kekurangan-kekurangan dalam implementasi hubungan kedua lembaga tersebut, bahkan menurut Mardani Ali Sera dari fraksi PKS, beliau beranggapan bahwa hubungan eksekutif dan legislatif bersifat pragmatis, tidak kolaboratif, dan tidak sinergis, daintara hubungan kedua lembaga pemerintahan tersebut. Padahal menurut penemuan yang ditemukan oleh peneliti dilapangan, justru hubungan eksekutif dan legislatif di 2014-2019 berjalan dengan sangat kolaboratif, walaupun memang di beberapa agenda kebijakan juga terdapat kritik-kritik keras dari partai oposisi di parlemen, namun pada kenyataanya hubungan eksekutif dan legislatif berjalan sangat sinergis. Hal ini dapat kita 
lihat dengan jelas, di akhir masa jabatan 2014-2019, baik eksekutif maupun legislatif memiliki kesamaan sikap pada RUU KPK dan RKUHP, mereka sama-sama mengehendaki bahwa kedua UU ini dapat segera di laksanakan ke publik. hal ini merupakan dampak bahwa memang eksrkutif memiliki dukungan suara di parlemen bahkan sampai 75\%, terbukti dari beberapa partai politik, hanya meninggalkan gerindra dan PKS yang terus beroposisi. Itupun dalam beberapa kesempatan mereka juga cenderung diam dan tidak segalak PDIP pada 2004-2009 saat beroposisi dari SBY.

Dari beberapa temuan-temuan penulis dilapangan, ada beberapa poin yang penulis simpulkan dari implementasi hubungan eksekutif dan legislatif. Temuan tersebut adalah, bahwa pada masa kepemimpinan presiden Jokowi 2014-2019 eksekutif yang menguasai mayoritas suara di parlemen dapat menimbulkan dugaan-dugaan praktik-praktik oligarki, hal ini dipicu dari kurangnya pengawasan yang berjalan dari legislatif, belum lagi suara oposisi yang ditekan, juga menghilangkan Check and Balance diantara keduanya, dan berujung kepada diuntungkannya segelintir orang atau kelompok. Fenomena ini, dapat kita lihat dari setiap kebijakan yang digodok sampai yang paling akhir adalah kebijakan RUU KPK dan RKUHP, pada kedua kebijakan itu dengan kasat mata dapat kita lihat bahwa memang parlemen seperti tukang ketik yang tidak memiliki suara, ketika eksekutif mengatakan mendukung, seketika dengan singkat hasil dari kedua UU tersebut hampir rampung lalu mendapatkan reaksi dari publik. Ini menunjukan bahwa memang eksekutif memiliki hegemoni penuh terhadap legislatif, belum lagi di akhir masa kepemimpinan 2014-2019, partai-partai politik cenderung tidak berani bicara banyak, karna sudah lebih dahulu ada kontrak kerjasama pemilu 2019, hal ini berpengaruh terhadap gagalnya penerapan Demokrasi modern di Indonesia.

Lebih lanjut, temuan-temuan peneliti di lapangan, sejalan dengan hasil penelitian dari Linz, namun linz lebih melihat jika eksekutif tidak mendapatkan suara dukungan dari mayoritas legislatif maka akan bersifat memusuhi legislatif, hal ini berdampak kepada beradunya dua kekuatan pemerintahan, yang merasa memiliki legitimasi langsung dari rakyat, dan berakhir dengan deadlock. Hal ini dapat berimbas kepada lemahnya Demokrasi, atau yang paling parah adalah gagalnya pemerintahan.(Linz, 1994: 114). Lalu tambahan temuan dari penulis, bahwa eksekutif yang juga mendapatkan dukungan dari hampir mayoritas partai-partai politik di parlemen, dapat menimbulkan praktik-praktik oligarki di sekitaran elit politik. Dan hal ini dapat kita lihat fenomena nyatanya di akhir 
masa kepemimpinan Presiden Jokowi periode 2014-2019, dimana pada RUU KPK, seluruh partai politik di parlemen bersama-sama dengan dengan eksekutif menyetujui adanya Revisi Undang-undang KPK, padahal respon dari msayarakat waktu itu menunjukan perlawanan dan ketidak setujuan akan keputusan pemerintah.

\section{Dampak Menguatnya Sistem Presidensial dalam Hubungan Eksekutif dan Legislatif pada Era Kepemimpinan Joko Widodo Periode 2014-2019 Bagi Demokrasi Modern di Indonesia}

Sistem pemerintahan Presidensial sering memiliki masalah yang sudah ada sejak lama. Linz menyebut fenomena ini sebagai the Perils of presidentalism. (Linz, 1994: 114). Sistem presidensial memiliki karakteristik dasar keterpisahan antara eksekutif dan legislatif dan baik Presiden mapun anggota legislatif sama-sama dipilih langsung oleh rakyat lewat pemilu. Ada beberapa masalah bawaan di dalamnya yaitu, dual legitimacy. Karna sama-sama dipilih rakyat maka baik presiden maupun legislatif sama-sama memiliki legitimasi kuat.(Diyadi Hanan, 2015: 2). Kedua-duanya sama-sama tidak bisa memproklamirkan diri sebagai representasi rakyat, karna kedua-duanya sama-sama dipilih rakyat, jika ada konflik diantara kedua lembaga tersebut, maka yang terjadi adalah kebuntuan. Selanjutnya rigidity, baik legislatif maupun presiden sama-sama punya masa jabatan yang tetap. Kecuali karena alasan-alasan seperti kriminal atau penghianatan terhadap konstitusi, seorang Presiden tidak tidak bisa di berhentikan/atau di jatuhkan di tengah jalan. Yang selanjutnya majoritan tandency, ketika seorang presiden memiliki kecendrungan mengabaikan legislatif atau ketika presiden menganggap legislatif tidak bersahabat, maka dia bisa mencari celah konstitusional atau politik, untuk memperluas kekuasaannya. (Diyadi Hanan, 2015: 2). Hal ini dapat berakibat pada makin melemahnya legislatif dan kekuasaan bisa menjadi oligakri atau otoriterisme. Alasan inilah mengapa sistem presidensial lebih rawan mengalami kejatuhan Demokrasi.

Masalah dalam Presidensial bisa lebih buruk, ketika dia juga berjalan beriringan dengan multipartai. (Mainwaring, 1939: 61). Dalam sistem multipartai biasanya dukungan mayoritas legislasi didapat dengan dukungan partai koalisi. Namun karna presiden tidak bergantung kepada parlemen intensif membentuk koalisi tidak sebesar sistem parlementer. Namun lobby-lobby politik dapat dengan mudah membuat presiden 
menguasai parlemen dengan membagi jatah kursi terhadap partai-partai politik. Bahkan menurut Mark P,Jones:

"all evidence indicates the functioning of presidential system is greatly enhanced when the president is provided with a majority or near-majority legislature. "(Djaya Hanan, 2015: 3).

Dapat diartikan memperkuat sistem presidensial sangat tergantung dengan kesediaan dukungan politik yang tersedia di parlemen bagi presiden. Dukungan yang memadai itu diartikan secara oprasional dengan dukungan partai-partai yang lebih dari $50 \%$, atau dukungan mayoritas. Jika seorang presiden memiliki dukungan presiden kurang dari angka tersebut, maka sulit bagi seorang presiden untuk menjalankan pengaruh pemerintahannya. Akibat dari hal ini adalah kurang atau tidak berfungsinya sistem presidensial atau akibat yang lebih parah adalah kegagalan pemerintahan. (Diyadi Hanan, 2015: 3).

Sebenarnya di Indonesia sendiri dampak dari praktik menguatnya sistem Presidensialisme sudah bisa dirasakan sejak jaman presiden Susilo Bambang Yudhoyono, sejak era pak SBY pasang surut antara hubungan eksekutif dan legislatif sudah terlihat jelas, sebagai konsekuensi sebagai pemerintahan minoritas yang awalnya tidak mendapat dukungan mayoritas di parlemen, pada periode partama pemerintahan SBY partai demokrat hanya mengantongi 57 kursi dari keseluruhan kursi di DPR. Demikian pada awal pemerintahan kedua, hanya mengantongi 150 kursi. Begitu juga pada masa pemerintahan Joko Widodo, PDIP hanya berhasil mengantongi 109 kursi di DPR. Langkah yang diambil untuk menambah dukungan di parlemen adalah dengan membentuk koalisi partai politik pendukung pemerintah. Namun demikian pembentukan koalisi partai-partai di parlemen sebagai pendukung pemerintah, nyatanya tidak dapat memberikan jaminan untuk stabilitas dan efektivitas jalannya roda pemerintahan. Koalisi ini justru merupakan pintu-pintu dari maraknya praktik-praktik oligarki di Indonesia. Karna pada kenyataannya ini hanya menguntungkan segelintir orang saja. Hal ini mengakibatkan DPR kehilangan marwah independensinya saja, karna dari kebanyakan kasus, di tengah dikuasainya parlemen oleh partai-partai pendukung pemerintah, maka DPR bekerja hanya sebatas sebagai lembaga tukang stempel dan tanda tangan saja. Hal ini selaras dengan apa yang di sampai kan oleh Yosef T. Badewoda yang merupakan anggota DPR RI 2014-2019 dari fraksi Demokrat. Beliau berpendapat bahwa DPR dan partai-partai koalisi di parlemen hanya menjalankan sistem ASB (Asal bapa senang), jadi 
seriap program kerja pemerintah yang membutuhkan tanda tangan DPR dengan mudah nya bebas melanggeng tanpa ada analisa dan kajian lebih dalam terlebih dahulu di parlemen.” (Melalui wawancara pribadi, pada tanggal 27 Februari 2020, Pukul 15.00).

Dalam situasi seperti ini, sebetulnya peran oposisi sangat dibutuhkan dalam rangka menjalankan amanat konstitusi yang baik dan benar, untuk menghindari terbentuknya kebijakan-kebijakan karet yang menguntungkan segelintir orang ataupun kelompok. Namun kerap kali, oposisi tidak bisa banyak bisa di berbagai kesempatan, karna jumlah perwakilan dan suara yang terbatas di parlemen. Seperti contoh pada pemerintahan Presiden Jokowi 2014-2019, dimana partai oposisi hanya di duduki oleh Gerindra dan PKS, adapun Demokrat tidak menyatakan diri secara gamblang bahwa mereka oposisi, melainkan mereka bertindak sebagai partai netral yang bebas mengkritisi siapa dan apa saja. Kuatnya partai pendukung pemerintah di parlemen kerap kali membuat partai oposisi tidak banyak bicara, menurut Yosef T.Badeweoda (Wawancara Pribadi, pada tanggal 27 Februari 2020) mengatakan, bahwa partai oposisi selalu kalah dalam hal pengambilan voting di parlemen, karna jumlahnya yang tidak seimbang sejak sepeninggalan Golkar. Jadi semua hanya iya-iya dan hore-hore saja. Hal ini menunjukan bahwa sebetulnya terjadi penghambatan jalannya check and balance di dalam parlemen sendiri, karna lembaga yang seharusnya mengkritisi dan menjadi pengingat pemerintah, justru malah dikuasai oleh eksekutif lewat parwakilan partai-partainya di parlemen.

Sebenarnya hal ini bisa berdampak langsung terhadap pelemahan Demokrasi, pada akhirnya sistem checking power with power tidak akan terlaksana, karna lembaga pengawas eksekutif justru menjadi bagian pembentukan sebuah pemerintahan yang tidak transparan dan yang terburuk adalah terbentuknya sistem pemerintahan oligarki. Sebetulnya dalam hal ini parpol juga ikut andil dalam proses gagalnya implementasi dari hubungan eksekutif dan legislatif. Partai politik memiliki fungsi sebagai lembaga komunikasi politik sosialisasi dan rekruitmen politik, namun sayangnya hari ini parpolparpol gagal melaksanakan tugasnya dengan baik, sehingga hal ini juga mempengaruhi kinerja demokrasi. Bahkan dengan kasat mata dalam proses koalisi dalam setiap pemilu, komunikasi politik yang semestinya dilakukan ke masyarakat justru tidak terjadi. Justru yang terjadi adalah komunikasi politik diantara elit partai dan calon presiden, sehingga koalisi yang terbentuk terkesan koalisi transaksional. Singkatnya permasalahan yang terjadi dari kegagalan impelemntasi hubungan eksekutif dan legislatif adalah gagalnya 
partai poltik menjalankan tugas dan fungsinya. Sehingga berimbas kepada kegagalan Demokrasi di Indonesia.

Padahal efektivitas dan stabilitas jalannya satu pemerintahan di satu negara ditentukan oleh optimalisasi fungsi dari berbagai institusi-institusi politik yang hadir di negara tersebut, baik oleh masing-masing institusi secara mandiri, maupun dalam relasi antara institusi tersebut. Selain itu, praktik politik pragmatis atau politik transaksional membuat partai-partai sering kali menghitung insentif politik jangka pendek yang tidak hanya menganggu efektivitas dan stabilitas politik tapi juga kesejahteraan publik. Semua ini merupakan dampak dari menguatnya sistem Presidensial dari hubungan eksekutif dan legislatif terhadap Demokrasi modern.

\section{PENUTUP}

Jika kita membaca tentang penerapan sistem presidensial dalam demokrasi modern di dalam hubungan eksekutif dan legislatif pada era Presiden Joko Widodo 20142019, maka dapat kita simpulkan bahwa implementasi hubungan eksekutif dan legislatif pada era kepemimpinan presiden Joko Widodo terjalin karena dasar politik transaksional. Hal ini tidak akan membangun pola demokrasi yang sehat, justru membentuk pola demokrasi yang berjalan lesu seiring dengan perkembangan waktu. Selain itu, dari aspek koalisi partai-partai pendukung eksekutif juga akan melahirkan sebuah kekuatan yang tahan kritik, yang arah berjalannya sudah diatur oleh partai politik, jadi partai politik memiliki wewenang untuk mengatur kadernya di parlemen, di sisi lain menteri-menteri yang berasal dari parpol pun ada dibawah kendali parpol. Dengan demikian, tergantung bagaimana tawar - menawar antara eksekutif dan partai politik, agar presiden mendapatkan dukungan penuh di parlemen.

Lalu jika kita membaca tentang dampak hubungan eksekutif dan legislatif pada era kepemimpinan Joko Widodo periode 2014-2019 bagi sistem presidensial di era demokrasi modern, dapat kita ambil kesimpulan bahwa dampak menguatnya sistem presidensial yakni ketika eksekutif mendapat dukungan dari partai-partai mayoritas di parlemen dan kekuatan oposisi yang tidak seimbang, maka akan membentuk pola-pola oligarki, yang hanya menguntungkan sebagian elit politik di Indonesia. Secara tidak langsung hal ini membunuh budaya check and balance yang memang seharusnya sudah berjalan sejak lama di dalam sistem politik Indonesia. Mengingat begitu pentingnya peran legislatif sebagai lembaga penyeimbang ekskutif jika sudah berjalan diluar konstitusi, hal 
ini yang disebut dengan checking power with power. Lambat laun karna sudah tidak adanya budaya check and balance antara ekskutif dan legislatif, maka dampaknya adalah melemahnya Demokrasi di Indonesia.

\section{DAFTAR PUSTAKA \\ Buku}

Dahl, Robert, (Ed) Political Opposition in Western Democracies. New Haven and London. Yale University Press.

Harrison, Lisa. Metodologi Penelitian Politik, Jakarta: Kencana, 2009.

Inu Kencana Syafiie, Sistem Pemerintahan Indonesia, Rineka Cipta, Jakarta, 2002.

Inu Kencana Syafiie, Pengantar Ilmu Pemerintahan, Bandung: PT. Revika Aditama. 2011.

Linz, J.J. (1990), Presidentialism in Latin America: Does it make different?, In. J.J. Linz \& A.Venezuela (Eds.). Baltimor and London: John Hopkins University Press.

Muhtadi, Burhanudin, Perang Bintang 2014: Konstelasi Prediksi Pemilu dan Pilpres, PT.Mizan Publika, Jakarta, 2013.

Mochtar Mas'oed, Negara, Kapital dan Demokrasi, cetakan kedua, Pustaka Pelajar, Yogtyakarta, 1999.

Nazir, Muhammad. Metode Penelitian, Bandung: Remaja Rosdakarya, 1986.

Nawawi, Hadari. Metode Penelitian Ilmiah, Jakarta: Rineka Cipta, 1994.

Susanto, Azhar, 2013, Sistem Informasi Akuntansi, Bandung: Lingga Jaya.

Sarundjang, S.H. (2012), Babak Baru Sistem Pemerintahan, Jakarta: Kata Hasta Pustaka.

Saldi Isra, Pergeseran Fungsi legislative: Menguatnya model Legislasi Parlementer dalam Sistem Presidensial Indonesia, Rajawali Pers, Jakarta, 2010.

\section{Jurnal :}

Hanan, Djaya, Memperkuat Presidensialisme Multipartai di Indonesia: Pemilu Serentak, Sistem Pemilu, dan Sistem Kepartaian. SMRC, 2015. Firman Noor, Oposisi Dalam Kehidupan Demokrasi: Arti Penting Keberadaan Oposisi Sebagai Bagian Penguatan Demokrasi di Indonesia, Vol.42, 2016.

H.M.Thalal, Teori Demokrasi dalam Wacana Ketatanegaraan Persoektif Pemikiran Hans Kalsel, Yogyakarta, Vol.1 No.1. Linz, J.J, (1990), The Perils of Presidentialism. Journal of Democracy, Winter. 
Martini Rina, Pemilihan Pejabat Negara pada Lembaga Negara Penunjang Dalam Sistem Pesidensial: studi kasus KPU RI Priode 2017-2022. Jurnal Ilmu Politik. Vol.10 No.1. 2019.

Mainwaring, Scott, (1993), Presidentialism Multipartism, and Democracy: The Difficult Combination, Comprative Political Studies, 26 (2).

Mc, Millian dan Schumacher, Research and Education, 2001. Miles, MB dan AM Hubrman. Qualitative Data Analysis: A Sourcebook of New Methods, SAGE. Beaverly Hills.

Sulisworo, Hibah Materi Pembelajaran Non Konvensional 2012: Demokrasi, Jakarta: Universitas Ahmad Dahlan, 2012.

Suntikno Pradi, Prahara Presidensial dan Parlementer, Universitas Islam Indonesia Jogjakarta, Vol.2, No.3, 2007.

Tuswoyo Admojo, Peran partai oposisi di parlemen pasca pemilu 2014, Universitas Stiami Jakarta, Vol.1, No.2, 2016.

Pendapat dari Jean Jequin Rousseau, Du Contract Social, (perjanjian social), cetakan pertama, Visimedia, Jakarta, 2007.

Yin, R.K. (2002). Case Study Research: Desigen and methods (2rd ed.). Thousand Oaks, CA: Sage.

\section{Internet :}

Beritabuanna.co.2014. "Sikap Gerindra Soal Kenaikan Harga BBM Melempem."22 November.nasional.sindonews.com/... (4 Januarit 2020).

CNN Indonesia. 2014. "Sikap Kader PDIP Menolak BBM Dinilai Aneh.” 6 November www.cnnindonesia.com/.../20141106145717...(4 Januari 2020).

Kompas.com. 2014. "Aburizal: Kenaikan Harga BBM Ujian Pertama JokowiJK."24Oktober.http://nasional.kompas.com/read/2014/10/24/18171001/Aburizal. Kenaikan.Harga.BBM.Ujian. Pertama.Jokowi-JK (12 Januari 2020).

Kompas.com. 2014. "KIH Ingin Pembagian Proporsional Kursi Pimpinan”, 1 November. nasional.kompas.com/.../2014/11/(27 Januari 2020) www.toswari.ac.id. diunggah pada 16 April 2019.

\section{Daftar Narasumber}

Dave Laksono anggota DPR RI dari Fraksi Golkar tanggal 25 Januari 2020, Pukul 12.00 WIB.

Yosef T. Badewoda anggota DPR RI 2014-2019 dari Fraksi Demokrat tanggal 27 Januari 2020, Pukul 15.00 WIB. 
Mardani Ali Sera anggota DPR RI Fraksi PKS tanggal 05 Februari 2020, Pukul 18.00 WIB 